\title{
ETHICS IN CLINICAL RESEARCH: IS ETHICS INVOLVED INTO THE PHARMACY STUDIES IN EUROPE?
}

Viera Žufková, Ján Klimas, Ján Kyselovič, Michal Vivoda, Marián Šuráb, Comenius University, zufkova@fpharm.uniba.sk

\begin{abstract}
One of the key questions in medicine nowadays is the ethics and its maximum involvement into medical profession. The absence of ethics is very notable in public and professional relations. In spite of the fact that the pharmacy profession was separated from the medical profession in the 13th century by the emperor Frederic II, the ethics is involved into pharmacy study in minimum amount. In the article there is presented the ethics inclusion into pharmacy study in 31 Universities of the European Union (EU). The method of our research was the analysis of 31 WebPages of Faculties of Pharmacy in the EU. The ethics is taught in the $45 \%$ study programmes. It is mostly a part of syllabus of master programme (Czech Republic, Estonia and Portugal) or bachelor programme (Slovakia). We have not managed to find a full study plan in $13 \%$ of study plans. As the ethics remains the crucial part of the pharmacy profession, there is a great importance of its involvement into the pharmacy study. The Code of Conduct for Pharmacy students with its seven principles shall be a part of ethical preparation of future pharmacists in Europe.
\end{abstract}

UDC Numbers: 177, 304, 613.8, 615, DOI: 10.12955/cbup.2013.56

Key words: absence of ethics, code of conduct, ethics, ethical principle, pharmacist, pharmacy study

\section{Introduction}

In these demanding times when ethics more and more shows importance of its presence in pharmaceutical work the WHO (2006) established the affirmation that pharmacists should move from behind the counter and start serving the public by providing care instead of pills only. The right approach of active ethical problem solving is very essential to one who ponders the value of the pharmacy profession and the relationship of pharmacists with their patients.

\section{Ethics}

Ethics is a philosophical discipline which systematically studies the moral site of human action. It is a "theory of morality." It seeks to define ethical concepts (categories), looks for a logical connection between them (ethics, standards) and allows systematic ethical evaluation of human action and behaviour (ethical theory) and any guidance on logically arranged and formulated reasons (Glasa, 2009).

\section{Absence of ethics in healthcare}

Institute of Medicine of the National Academies has recommended that health care should become:

- patient-centred (coordinated, integrated), 
- team-delivered (interprofessional),

- evidence-based,

- informatics-supported,

- safer; more efficient and more effective,

- engaged in continuous quality improvement (IOM, 2013).

These recommendations could be also applied to pharmacy in challenging times. New reflection of pharmaceutical care integrates pharmacists into whole patient care in following tasks: prevention, availability of treatment, monitoring of treatment in order to ensure effectiveness, quality of life and the real financial cost of medication.

\section{Methods and Results}

Throughout the last years there has been stabilized several challenges about the ethics in the study of pharmacy. These issues have been forming the relation between the future pharmacist and patient.

Unfortunately the articles which dedicate their attention to the ethics in pharmacy do not reach the number of 50 each year; however articles with medical ethics reach number of 2000. Figures 1 and 2 depict the articles and studies that focus on the ethics in medicine and in pharmacy.

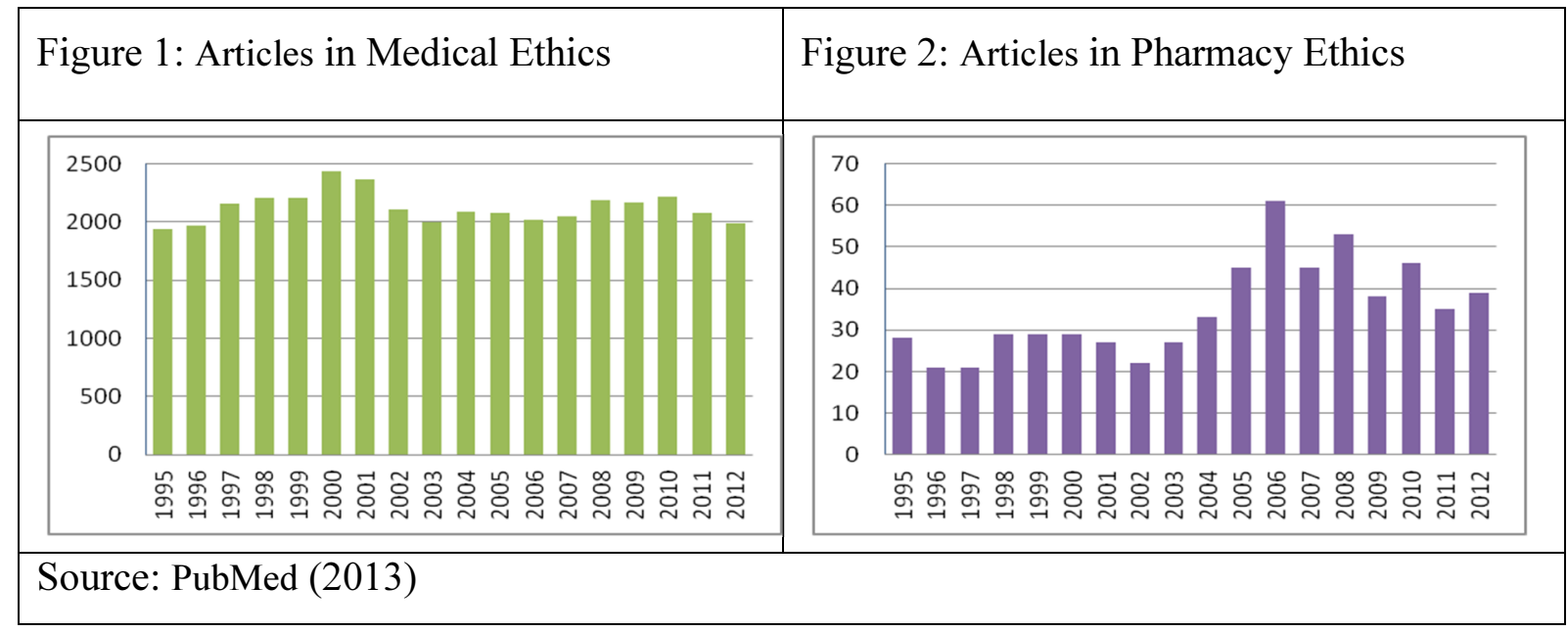

We have researched 31 Faculties of Pharmacy around the European Union via their WebPages and analysed the inclusion of the ethics into the structure of pharmacy study (see Appendix 1). The ethics is taught in the $45 \%$ study programmes. It is mostly a single part of syllabus of master programme (Czech Republic, Estonia and Portugal) or bachelor programme (Slovakia).

Compulsory study of ethics (as a single subject or combined with law) in the study programme was identified in $67 \%$ and voluntary study programmes which include also ethic approach were reached in $20 \%$. We have not managed to find full study plan in $13 \%$ of study plans but we cannot exclude some ethical issues being a part of other obligatory or voluntary subject. There is omitted any unifying approach in teaching ethics at European universities. However the appropriate model is offered by University of London, UCL school of Pharmacy. The Code of Conduct for Pharmacy students can be easily found in their UNI webpage, which in our opinion could be taken as the basic ethical knowledge of all pharmacy students around the European countries and involved in the compulsory study syllabus. 


\section{Discussion}

Pharmacy study prepares students to go into a profession. Pharmacy is one of registered healthcare professions and carries privileges and responsibilities. The pharmacy student must state he is able to exercise those privileges and bear those responsibilities. This means he must manner himself professionally at all times. According to Royal Pharmaceutical Society of Great Britain, the Code of Conduct for Pharmacy students (the Code of Conduct) applies to him from the first day he graduates. The Code of Conduct applies both on and off university grounds. He needs to remember that whenever he is, he represents the pharmacy profession and his university.

The Code of Conduct has been authorized by the Council of University Heads of Pharmacy (CCPS, 2010) and the British Pharmaceutical Students' Association. It is based on the seven principles, ethics and performance. In the following lines we will expose these principles in pharmacy study. It will help the student develop understanding of what is to be a pharmacist.

The Code of Conduct consists of seven principles:

1. Make patient his first concern.

2. Use his professional judgement in the interests of patients and the public.

3. Show respect for others.

4. Encourage patients and the public to participate in decisions about their care.

5. Develop his professional knowledge and competence.

6. Be honest and trustworthy.

7. Take responsibilities for his working practices (CCPS, 2010).

The Royal Pharmaceutical Society of Great Britain set up the principles that the pharmacist must pursue and they are designed to meet their obligations as the professional pharmacists and pharmacy technicians.

The Code of Ethics for Pharmacists and Pharmacy Technicians carries obligations and privileges. It requires the pharmacists to:

- develop and use their professional knowledge and skills for the benefit of those who seek their professional services,

- maintain good professional relationship with others, and

- act in a way that promotes confidence and trust in the pharmacy professionals.

The American Pharmaceutical Association in 1994 prepared and supported the principles that shape the fundamental basis of the roles and responsibilities of pharmacists. These principles, based on moral obligations and virtues, are established to direct pharmacists in relationships with patients, health, professionals and society.

On the contrary to British Code of Ethics, the American consists of eight principles. They are similar in three points:

No. 3: A pharmacist respects the autonomy and dignity of each patient. This principle accounts the fourth principle in British code: Encourage patients and the public to participate in decisions about their care. A pharmacist promotes the right of self-determination and recognizes individual self-worth by encouraging patients to participate in decisions about their health. 
No. 4: A pharmacist acts with honesty and integrity in professional relationship. British principle no. 6 claims similar message: Be honest and trustworthy, embraces that pharmacist has a duty to tell the truth and act with conviction of conscience.

No. 5: A pharmacist maintains professional competence. This principle is connected with the British code principle no. 5: Develop his professional knowledge and competence. A pharmacist has a duty to maintain knowledge and abilities as new medications, devices and technologies become available and as health information advances.

In Slovakia the ethics in the pharmacist's profession is regulated by the Code of Ethics of the Pharmaceutical Industry in Slovakia (CEPI), which was revised in February 2012.

This Code regulates the presentiment of medicinal products for human use subject to medical prescription to healthcare professionals, as well as promotional activities towards healthcare professionals and the communication with them and reciprocal relations between healthcare professionals and pharmaceutical companies. This Code also modifies relations between Member and the patient organizations and decision-makers.

The intention of the Code is not to control or to standardize the provision of non-promotional medical, scientific and accurate information; nor it is aimed at controlling or regulating activities directed towards the general public and related solely to medicinal products which are not subject to medical prescription (CEPI, 2012).

\section{Conclusion}

The problematic of ethics involvement into pharmacy study and pharmacy profession still remains in the agenda of professional pharmacy authorities. The attention, which is paid to the ethical approach, needs to be increased as soon as possible. There has to be also enlarged the number of articles and studies which focus on the ethics in pharmacy study and profession. After finishing the studies the pharmacy students should completely understand the ethical attitude to their profession. With the Code of Conduct they become fully competent to support the ethical principles, demonstrate respect for the dignity, views and rights of others and take responsibility for ensuring their knowledge and skills are up-to-date and that they maintain their competence. Let us prepare our students to become the ethical pharmacists.

\section{References}

American Pharmacists Association (1994). Code of ethics. Retrieved March 20, 2013, from http://www.pharmacist.com/code-ethics

Ethics Committee. (2012). Code of Ethics of the Pharmaceutical Industry in Slovakia (CEPI). Bratislava, Slovakia: SAFS.

Glasa, J. (2009). Stručný prehl’ad biomedicínskej etiky pre pracovníkov vo verejnom zdravotníctve [Brief overview of biomedical ethics for workers in public health]. Med. Etika Bioet., no. 16, p. 17-27.

General Pharmaceutical Council. (2010). Code of Conduct for pharmacy students (CCPS). London, England: The British Pharmaceutical Student's Association. 
Institute of Medicine of National Academies. (2013). Evidence Communication Innovation Collaborative: Effective communication about effective care. Retrieved March 13, 2013, from http://www.iom.edu/Activities/Quality/VSRT/ /media/Files/Activity\%20Files/Quality/VSRT/Core\%2 0Documents

PubMed. (2013). Manage filter. Results by year. Retrieved March 20, 2013, from http://www.ncbi.nlm.nih.gov/pubmed/?term=medical+ethics

PubMed. (2013). Manage filter. Results by year. Retrieved March 22, 2013, from http://www.ncbi.nlm.nih.gov/pubmed/?term=pharmacy+ethics

Royal Pharmaceutical Society of Great Britain. (2007). Code of Ethics for Pharmacists and Pharmacy technicians (CUHOP). London, England: Pharmaceutical Press.

Pharmacy. (2013). In Wikipedia, The Free Encyclopedia. Retrieved March 10, 2013, from http://en.wikipedia.org/wiki/Pharmacy

World Health Organization, International Pharmaceutical Federation (2006). Developing Pharmacy Practice. A focus on patient care. Geneva, Switzerland: Department of Medicines Policy and Standards. 
CBU INTERNATIONAL CONFERENCE ON INTEGRATION AND INNOVATION IN SCIENCE AND EDUCATION

\begin{tabular}{|c|c|c|c|c|}
\hline \multicolumn{5}{|c|}{ Appendix 1: Ethics included in Pharmacy studies } \\
\hline EU State & University & Faculty of Pharmacy & Ethics & Specification \\
\hline Austria & University of Vienna & $\begin{array}{l}\text { Institute of Pharmaceutical } \\
\text { Chemistry }\end{array}$ & $\mathrm{X}$ & \\
\hline Belgium & Vrije Universiteit Brussel & $\begin{array}{c}\text { Faculty of Medicine and } \\
\text { Pharmacy }\end{array}$ & $\mathrm{X}$ & \\
\hline Bulgaria & Medical University - Sofia & Faculty of Pharmacy & $\mathrm{X}$ & \\
\hline Czech Republic & Charles University in Prague & Faculty of Pharmacy & $\sqrt{ }$ & Compulsory \\
\hline Czech Republic & $\begin{array}{c}\text { University of Veterinary and } \\
\text { Pharmaceutical Sciences Brno }\end{array}$ & Faculty of Pharmacy & $\sqrt{ }$ & Compulsory \\
\hline Denmark & University of Copenhagen & $\begin{array}{c}\text { Faculty of Pharmaceutical } \\
\text { Sciences }\end{array}$ & $\sqrt{ }$ & Voluntary \\
\hline Estonia & University of Tartu & $\begin{array}{c}\text { Faculty of Medicine, } \\
\text { Department of Pharmacy }\end{array}$ & $\sqrt{ }$ & Compulsory \\
\hline Finland & University of Helsinki & Faculty of Pharmacy & $\sqrt{ }$ & Voluntary \\
\hline France & University of Auvergne & Faculty of Pharmacy & $\sqrt{ }$ & Compulsory \\
\hline Germany & Free University of Berlin & Faculty of Pharmacy & $\mathrm{X}$ & \\
\hline Germany & University of Düsseldorf & $\begin{array}{l}\text { Scientific Institute of } \\
\text { Pharmacy }\end{array}$ & $\mathrm{X}$ & \\
\hline Greece & $\begin{array}{c}\text { National and Kapodistrian } \\
\text { University of Athens }\end{array}$ & Faculty of Pharmacy & $\mathrm{X}$ & \\
\hline Hungary & Semmelweis University & Faculty of Pharmacy & $\sqrt{ }$ & Unknown \\
\hline Italy & University of Bologna & Faculty of Pharmacy & $\mathrm{X}$ & \\
\hline Ireland & $\begin{array}{l}\text { Royal College of Surgeons in } \\
\text { Ireland }\end{array}$ & School of Pharmacy & $\sqrt{ }$ & Compulsory \\
\hline Latvia & Riga Stradiņ̌̌ University & Faculty of Pharmacy & $\sqrt{ }$ & Voluntary \\
\hline Lithuania & Kaunas Medical University & Faculty of Pharmacy & $\mathrm{X}$ & \\
\hline Malta & University of Malta & Faculty of Pharmacy & $\mathrm{X}$ & \\
\hline Netherlands & Utrecht University & Faculty of Pharmacy & $\mathrm{X}$ & \\
\hline Poland & Medical University of Warsaw & Faculty of Pharmacy & $\sqrt{ }$ & Compulsory \\
\hline Portugal & University of Lisbon & Faculty of Pharmacy & $\sqrt{ }$ & Compulsory \\
\hline Romania & $\begin{array}{l}\text { Carol Davila University of } \\
\text { Medicine and Pharmacy }\end{array}$ & Faculty of Pharmacy & $\mathrm{X}$ & \\
\hline Slovakia & Comenius University & Faculty of Pharmacy & $\sqrt{ }$ & Compulsory \\
\hline Slovakia & $\begin{array}{l}\text { University of Veterinary Medicine } \\
\text { and Pharmacy in Košice }\end{array}$ & Department of Pharmacy & $\sqrt{ }$ & Compulsory \\
\hline Slovenia & University of Ljubljana & Faculty of Pharmacy & $\mathrm{X}$ & \\
\hline Spain & Complutense University of Madrid & Faculty of Pharmacy & $\sqrt{ }$ & Compulsory \\
\hline Sweden & Uppsala University & Faculty of Pharmacy & $\mathrm{X}$ & \\
\hline $\begin{array}{c}\text { United } \\
\text { Kingdom }\end{array}$ & University of Brighton & $\begin{array}{l}\text { School of Pharmacy and } \\
\text { Biomolecular Sciences }\end{array}$ & $\mathrm{X}$ & \\
\hline $\begin{array}{c}\text { United } \\
\text { Kingdom }\end{array}$ & King's College London & Department of Pharmacy & $?$ & \\
\hline $\begin{array}{c}\text { United } \\
\text { Kingdom }\end{array}$ & University of London & UCL School of Pharmacy & $?$ & \\
\hline $\begin{array}{c}\text { United } \\
\text { Kingdom } \\
\end{array}$ & Cardiff University & Welsh School of Pharmacy & $\sqrt{ }$ & Unknown \\
\hline \multicolumn{5}{|c|}{ Notes: $\sqrt{ }$ - involved in the study, $X$ - not involved in the study, ? - not depicted clearly } \\
\hline \multicolumn{5}{|c|}{ Source: Webpages of researched Universities (see Appendix 2) } \\
\hline
\end{tabular}


CBU INTERNATIONAL CONFERENCE ON INTEGRATION AND INNOVATION IN SCIENCE AND EDUCATION

\begin{tabular}{|l|l|l|}
\hline \multicolumn{2}{|l|}{ Appendix 2: Webpages of researched Universities } & $\begin{array}{l}\text { Netherlands - } \\
\text { www.uu.nl }\end{array}$ \\
\hline Austria www.univie.ac.at & Greece http://en.uoa.gr & $\begin{array}{l}\text { Poland } \\
\text { www.wum.edu.pl/en }\end{array}$ \\
\hline Belgium www.vub.ac.be & Germany www.fu-berlin.de & Portugal www.ul.pt \\
\hline Bulgaria http://mu-sofia.bg & Germany www.uni-duesseldorf.de & $\begin{array}{l}\text { Romania } \\
\text { www.umf.ro }\end{array}$ \\
\hline $\begin{array}{l}\text { Czech Republic } \\
\text { www.cuni.cz/UKENG-1.html }\end{array}$ & Hungary www.semmelweis-univ.hu & $\begin{array}{l}\text { Slovakia } \\
\text { www.uniba.sk }\end{array}$ \\
\hline $\begin{array}{l}\text { Czech Republic } \\
\text { www.vfu.cz/index_en.html }\end{array}$ & Italy www.eng.unibo.it & $\begin{array}{l}\text { Slovakia } \\
\text { www.uvlf.sk }\end{array}$ \\
\hline $\begin{array}{l}\text { Denmark www.ku.dk/english } \\
\text { Estonia www.ut.ee/en }\end{array}$ & Ireland www.rcsi.ie & $\begin{array}{l}\text { Slovenia } \\
\text { www.uni-lj.si }\end{array}$ \\
\hline $\begin{array}{l}\text { Finland www.helsinki.fi/university } \\
\text { www.kcl.ac.uk/index.aspx }\end{array}$ & $\begin{array}{l}\text { Lithuania www.university- } \\
\text { directory.eu/Lithuania/Kaunas-Medical- } \\
\text { Academy.html }\end{array}$ & \begin{tabular}{l} 
Spain www.ucm.es \\
\hline United Kingdom www.cardiff.ac.uk
\end{tabular} \\
\hline France www.u-clermont1.fr & Malta www.um.edu.mt & $\begin{array}{l}\text { Snited Kingdom www.brighton.ac.uk } \\
\text { www.lon.ac.uk }\end{array}$ \\
\hline United Kingdom ww.rsu.lv/eng & \\
\hline
\end{tabular}

